\title{
Effects of Recombinant Human Insulin-like Growth Factor I on Glomerular Dynamics in the Rat
}

Raimund Hirschberg, Joel D. Kopple, Roland C. Blantz, ${ }^{*}$ and Bryan J. Tucker*

Division of Nephrology and Hypertension, Harbor-University of California at Los Angeles (UCLA) Medical Center, Torrance, California 90509; UCLA Schools of Medicine and Public Health, Los Angeles, California 90024; and *Division of Nephrology,

Veterans Administration Medical Center and University of California at San Diego School of Medicine, San Diego, California 92037

\begin{abstract}
This study was undertaken to investigate the mechanisms by which an infusion of recombinant human insulin-like growth factor I (rhIGF-I) increases GFR and renal plasma flow (RPF) in rats. Glomerular micropuncture studies were carried out in 14 nonstarved Munich Wistar rats and in 12 rats deprived of food for 60-72 h. Animals were given an intravenous injection and infusion of either rhIGF-I or vehicle. In both nonstarved and starved animals, the IGF-I injection and infusion increased the serum IGF-I levels, left kidney GFR, single nephron glomerular filtration rate (SNGFR), single nephron blood flow rate (SNBF), and single nephron plasma flow rate (SNPF). The increase in SNPF and SNGFR was in part due to a fall in efferent arteriolar resistance $\left(R_{E}\right)$; there was a tendency, not significant, for afferent arteriolar resistance $\left(R_{A}\right)$ to fall in comparison to controls. The increase in SNGFR was partly caused by a rise in SNPF but was primarily due to an increase in glomerular ultrafiltration coefficient $(L p A)$ to twice the control values. The increase in $\mathrm{LpA}$ resulted in an increase in SNGFR because the rats operated at ultrafiltration pressure disequilibrium. Control starved as compared with nonstarved rats had lower SNGFR, SNBF, and SNPF. This reduction was due to a tendency, not significant, for both $R_{A}$ and $R_{E}$ to be higher. Decreased SNGFR in food-deprived rats resulted from a reduced SNPF, a lower glomerular transcapillary hydrostatic pressure difference $(\Delta P)$, and possibly a somewhat reduced $L p A$. These data indicate that IGF-I increases SNGFR, SNPF, and SNBF primarily by increasing $L p A$ and also by decreasing $R_{E}$ without affecting $\triangle P$. Short-term starvation lowers SNGFR, SNPF, and SNBF primarily by decreasing $\Delta P$ and possibly by lowering $L p A$ and increasing $R_{A}$ and $R_{E}$. IGF-I reverses some of the glomerular hemodynamic effects of short-term food deprivation. (J. Clin. Invest. 1991.87:1200-1206.) Key words: glomerular ultrafiltration coefficient - single nephron glomerular filtration rate $\bullet$ starvation
\end{abstract}

\section{Introduction}

Insulin-like growth factor I (IGF-I) ${ }^{1}$ is a peptide hormone with a mol wt of 7,649 D which shares about half of its amino acid

Address reprint requests to Dr. Raimund Hirschberg, Division of Nephrology and Hypertension, C-1-A, Harbor-University of California at Los Angeles Medical Center, 1000 West Carson Street, Torrance, CA 90509.

Received for publication 18 July 1990 and in revised form 6 November 1990.

1. Abbreviations used in this paper: IGF-I, insulin-like growth factor I; LpA, glomerular ultrafiltration coefficient; $\Delta \mathrm{P}$, glomerular transcapil-

The Journal of Clinical Investigation, Inc.

Volume 87, April 1991, 1200-1206 sequence with proinsulin $(1,2)$. The hormone is synthesized and released from many cells and tissues including the liver and kidneys (1-5). IGF-I has been identified on glomeruli, proximal tubules, and collecting ducts $(6,7)$. IGF-I receptors have been demonstrated in cultured glomerular mesangial cells, proximal tubular epithelial cells, vascular endothelial cells, and vascular smooth muscle cells (8-11). In rats, the kidney IGF-I content increases during compensatory renal hypertrophy $(5,12-14)$, with feeding of high protein diets that promote renal hypertrophy (14), and during recovery from acute renal ischemic injury (15). Growth hormone injections, which also cause renal hypertrophy, also increase renal IGF-I levels (16).

Elevated circulating growth hormone is associated with increased renal plasma flow (RPF) and GFR $(17,18)$. Indeed, renal hemodynamics rise within several hours after a single injection of growth hormone, at about the same time that serum IGF-I concentrations increase (19). These findings suggested that IGF-I may increase RPF and GFR. This hypothesis was tested in food-deprived rats that were infused with IGF-I (20). The results showed that an intravenous infusion of IGF-I acutely increases RPF and GFR. Subsequently, Guler and associates reported that in two healthy men, subcutaneous injections of IGF-I for 3-5 d increase GFR and RPF $(21,22)$. This study was undertaken to examine the following questions in rats, using micropuncture techniques: $(a)$ the mechanisms at the glomerular level by which IGF-I may augment renal hemodynamics; and $(b)$ to further investigate the effects of food deprivation and the interactions of food deprivation and IGF-I infusion on the microcirculation and filtration in the glomerulus.

\section{Methods}

\section{General study design}

Studies were performed on normal rats that were fed laboratory chow (Study 1) or that were food-deprived (Study 2).

Study 1.14 male Munich Wistar rats (Harlan Sprague Dawley, Inc., Indianapolis, IN) were used. Animals had free access to standard laboratory chow and tap water. Food but not water was removed from the cages about $12 \mathrm{~h}$ before commencement of the micropuncture study.

The animals were prepared for the micropuncture measurements of glomerular dynamics as outlined below. At $\mathbf{4 0}$ min before starting the micropuncture measurements, during the period of equilibration, eight rats received an intravenous injection of recombinant human IGF-I (rhIGF-I; courtesy of Ciba Geigy Corp., Summit, NJ), $75 \mu \mathrm{g} / \mathrm{kg}$ in $0.3 \mathrm{ml}$ of Ringer's saline. This was followed by a sustained infusion of IGF-I, $250 \mu \mathrm{g} / \mathrm{kg}$ per $\mathrm{h}$, in Ringer's saline at a rate of $2.5 \mathrm{ml} / \mathrm{kg}$ per h.

lary pressure difference; $R_{\hat{A}}$, afferent arteriolar resistance; $R_{E}$, efferent arteriolar resistance; rhIGF-I, recombinant human IGF-I; SNBF, single nephron blood flow; SNFF, nephron filtration fraction; SNPF, single nephron plasma flow. 
The purified lyophilized rhIGF-I was dissolved in $0.1 \mathrm{M}$ acetic acid to form a stock concentration of $1 \mu \mathrm{g} / \mu \mathrm{l}$. Just before the individual studies, further dilutions for infusion were made with Ringer's saline. Six control animals were similarly treated but received an injection and infusion of the vehicle in Ringer's saline.

Study 2. 12 male Munich Wistar rats, obtained from a continuous colony bred and housed at the San Diego Veterans Administration Medical Center were studied with a protocol similar to Study 1. The animals were food-deprived for $2.5-3 \mathrm{~d}(60-72 \mathrm{~h})$ before the experiments but had free access to tap water. Six rats received an injection of rhIGF-I, $25 \mu \mathrm{g} / \mathrm{kg}$, followed by a sustained infusion of rhIGF-I, 75 $\mu \mathrm{g} / \mathrm{kg}$ per $\mathrm{h}$. The solution for injections and infusions was prepared as described for Study 1 . Six control rats were injected and infused with a similar volume of vehicle.

\section{Micropuncture determination of glomerular hemodynamics}

The micropuncture experiments were performed according to standard protocols (23). Rats were anesthetized with intraperitoneal Inactin (Byk-Gulden, Konstanz/Bodensee, Germany), $120 \mathrm{mg} / \mathrm{kg}$ body wt. A tracheostomy was performed using PE-240 tubing for the tracheostoma. PE-50 catheters were inserted into the left internal jugular vein, left femoral artery, and the bladder. The bladder was ligated around the catheter to minimize the residual bladder dead space. The rats were then placed on a servo-heating table, keeping the body temperature constant at $37^{\circ} \mathrm{C}$. The left kidney was exposed through a lateral abdominal incision and was placed in a lucite holder. The left ureter was ligated, and a PE-50 catheter was inserted into the ureter for collections of the urine excreted from the left kidney. The kidney was sealed in the holder with cotton, soaked with a $1 \%$ agar solution, and bathed continuously in normal saline at $37^{\circ} \mathrm{C}$.

An infusion of $\left[{ }^{3} \mathrm{H}\right]$ inulin (ICN Radiochemicals, Irvine, CA) in Ringer's solution at a concentration of $60 \mu \mathrm{Ci} / \mathrm{ml}$ (Study 1) or $80 \mu \mathrm{Ci}$ / $\mathrm{ml}$ (Study 2) was started at a rate of $1.8 \mathrm{ml} / \mathrm{h}$ (Study 1) or $1.5 \mathrm{ml} / \mathrm{h}$ (Study 2) and continued until termination of the micropuncture study. To substitute for plasma losses that occur with the surgical preparation and micropuncture and to maintain euvolemia, rat plasma was infused at a rate corresponding to $1 \%$ of body wt for the first hour, and continued at a rate equal to $0.15 \%$ of the animal's body wt per $h$ for the remainder of the micropuncture study. In Study 1, the rat plasma used for infusion was obtained from nonfasted donor rats, whereas the plasma used in the Study 2 animals was obtained from littermates that were also food-deprived for 2.5-3.0 d.

After starting the $\left[{ }^{3} \mathrm{H}\right]$ inulin infusion, $1 \mathrm{~h}$ was allowed for equilibration. $20 \mathrm{~min}$ into the equilibration period, the rhIGF-I or vehicle injection was given and the rhIGF-I or vehicle infusions were initiated at the doses and rates outlined above. All infusions were given via the jugular vein catheter, and hematocrits were maintained constant during the entire period of micropuncture measurements. Throughout the micropuncture study, the arterial blood pressure was measured with a pressure transducer (P23dB; Gould-Statham, Cleveland, $\mathrm{OH}$ ) connected to the femoral artery catheter and was recorded with a multichannel recorder (model 8805 C; Hewlett-Packard Co., Waltham, MA).

At the beginning and end of the micropuncture measurements, blood was collected from the femoral artery catheter to determine the hematocrit (HCT), the afferent (systemic) plasma protein concentration $\left(\mathrm{C}_{\mathrm{A}}\right)$, and the systemic $\left[{ }^{3} \mathrm{H}\right]$ inulin concentration. In addition, at the end of the micropuncture measurements, $150 \mu$ l of femoral arterial blood was obtained for measurement of the serum IGF-I concentration. Urine was collected from the left ureteral catheter continuously throughout the period of micropuncture to measure the whole kidney GFR.

Hydrostatic pressures in glomerular capillaries $\left(\mathrm{P}_{\mathrm{G}}\right)$, glomerular urinary spaces $\left(P_{B S}\right)$, proximal tubules $\left(P_{T}\right)$, and efferent arterioles $\left(P_{E}\right)$ were measured with a servo-nulling pressure sensor (Model 4A or 5A; Instrumentation for Physiology and Medicine, San Diego, CA) connected to a 1-3- $\mu \mathrm{m}$-tip glass pipette filled with $1.2 \mathrm{M}$ sodium chloride. Multiple measurements were made in each rat, and time-averaged values were recorded with a pressure transducer and a chart recorder. Five exactly timed $(3 \mathrm{~min})$ fluid collections were made from late proximal convoluted tubules with sharpened 9-11- $\mu \mathrm{m}$-tip pipettes that were filled with mineral oil lightly stained with Sudan black. A small amount of the oil was injected through the pipette into the tubular lumen to prevent downstream escape of tubular fluid during the collection.

In each rat, two to three blood collections were made from efferent arterioles (star vessels) using sharpened 13-16- $\mu \mathrm{m}$-tip glass pipettes. After completion of the blood collections the pipette tips were sealed with cyanoacrylate. The pipettes were then spun in a microhematocrit centrifuge to obtain serum for determination of the efferent arteriolar protein concentration $\left(C_{E}\right)$. When micropuncture measurements were concluded, the left kidney was removed, sliced into two halves along the long axis, partially freed from blood by blotting on filter paper, and weighed. Aliquots of systemic plasma and urine and the complete tubular fluid collections were counted in a Beta Counter (Beckman Instruments, Inc., Fullerton, CA) to measure the $\left[{ }^{3} \mathrm{H}\right]$ inulin radioactivity.

\section{Laboratory assays}

The afferent arteriolar (systemic) serum total protein concentration was measured with a Lowry assay $(23,24)$ using BSA (Study 1) or concentrated rat plasma (Study 2) as standard. For the determination of the efferent arteriolar protein concentration, two different approaches were used. In Study 1, an ELISA for rat albumin was used to measure the afferent and efferent serum albumin concentrations. The efferent serum protein concentration was calculated from the afferent protein concentration and the efferent/afferent albumin ratio. This approach is based on the assumption that the fluid filtration along the glomerular capillary concentrates the albumin to the same extent as the total protein. In Study 2, the Lowry protein assay, modified to a smaller, 7-nl vol, was used as previously described (23).

The rat serum albumin ELISA was developed from the method of Yoshioka and associates (25). Aliquots of afferent and efferent sera were pipetted with an exactly calibrated nanoliter pipette (usually 6.0 $\mathrm{nl})$ under a stereomicroscope, into sample buffer (0.025 M EDTA-Na, pH 7.3, containing $0.05 \%$ gelatin) to result in a $10^{-6}$ dilution of plasma. With each batch of specimens a quality control sample of rat plasma was also assayed. Quality controls and samples were further diluted with sample buffer to $1: 5-1: 8 \times 10^{-6}$ before assay. For the standard curve, a stock solution $(100 \mathrm{ng} / \mathrm{ml})$ of purified rat albumin lyophylisate (Cappel, Division of Organon Teknika Corp., West Chester, PA) in sample buffer was stored at $-20^{\circ} \mathrm{C}$. For construction of the standard curve, the stock solution was further diluted with sample buffer to generate serial standards ranging from 1.0 to $12.0 \mathrm{ng} / \mathrm{ml}$.

The assay was performed on 96-well flat bottom polystyrene ELISA plates (Corning Glass Works, Corning, NY). The first column of wells was used for blanks in the final enzyme end point reaction and was not coated with primary antibody. All remaining wells were coated with $100 \mu \mathrm{l}$ of purified rabbit anti-rat albumin IgG (Cappel), $5 \mu \mathrm{g} / \mathrm{ml}$, in

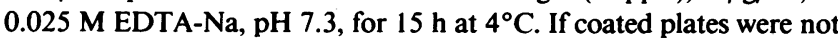
used immediately, wells were washed once with $300 \mu \mathrm{l}$ of washing buffer $\left(0.15 \mathrm{M} \mathrm{NaCl}, 0.02 \mathrm{M} \mathrm{NaH}_{2} \mathrm{PO}_{4}, \mathrm{pH} \mathrm{7.3,0.05 \%}\right.$ Tween 20$)$, blotted dry, and stored at $4^{\circ} \mathrm{C}$ for $\leq 2$ wk. Before use, all wells were washed three times with $300 \mu \mathrm{l}$ of washing buffer, and plates were blotted dry. $200 \mu \mathrm{l}$ of blocking buffer (0.025 M EDTA-Na, ph 7.3, containing $2.5 \%$ ( $w t / v o l)$ gelatin) was pipetted into each well except the first column of wells, and incubated for $30 \mathrm{~min}$ at $37^{\circ} \mathrm{C}$. Thereafter, wells were emptied with vacuum but not washed.

Standards, zero standard (sample buffer), quality controls, and samples at respective dilutions were pipetted in triplicates into respective wells $\left(100 \mu \mathrm{l}\right.$ per well) and incubated at $37^{\circ} \mathrm{C}$ for $1 \mathrm{~h}$. All wells were washed three times with $300 \mu \mathrm{l}$ of washing buffer and blotted dry. To each well, $100 \mu \mathrm{l}$ of the second antibody solution was added and incubated for $1 \mathrm{~h}$ at $37^{\circ} \mathrm{C}$. The second antibody, peroxidase-labeled IgG fraction of sheep anti-rat albumin, was diluted 1:10,000 in blocking buffer. To eliminate unbound second antibody, all wells were washed five times with washing buffer $(300 \mu \mathrm{l} /$ well), and plates were blotted dry. Thereafter, $100 \mu \mathrm{l}$ of reaction solution, $0.252 \%$ (wt/vol) of $o$ phenylenediamine (Sigma Chemical Co., St. Louis, MO) and $0.012 \%$ 
(vol/vol) $\mathrm{H}_{2} \mathrm{O}_{2}$ in reaction buffer $(0.2 \mathrm{M}$ Tris- $\mathrm{HCl}, 0.15 \mathrm{M} \mathrm{NaCl}, \mathrm{pH}$ 6.0) was added to each well, including those of the blank column, and incubated at room temperature in the dark for $30 \mathrm{~min}$.

The reaction solution was prepared only minutes before and kept in the dark until use. The peroxidase-substrate reaction was stopped by adding $50 \mu$ l of stopping solution ( $0.1 \mathrm{M}$ sodium sulfite in $4 \mathrm{M}$ sulfuric acid) to each well. The absorption of each well was measured against the blanks at $492 \mathrm{~nm}$ in an ELISA plate reader (Titertek Multiscan; Flow Laboratories, Inc., McLean, VA). The color that develops after adding the stopping solution is stable after $10 \mathrm{~min}$ and for at least $12 \mathrm{~h}$. The absorption of the zero standard, reflecting nonspecific binding, was subtracted from the absorption of standards and samples.

The standard curve between albumin concentrations of 1.0-12.0 $\mathrm{ng} / \mathrm{ml}$ usually displays a linear regression coefficient $(r) \geq 0.997$. The interassay coefficient of variation was $7.2 \%(n=7$ assays with one control sample per assay, measured in triplicate). The intraassay coefficient of variation using five to seven quality control samples per assay, each analyzed in triplicate, was between 2.6 and $6.7 \%$ (mean $5.1 \%, n$ $=9$ assays). The serially diluted rat plasma and rat albumin standard solutions result in parallel linear curves when the dilution factor is plotted against the corrected absorption.

For the measurement of serum IGF-I levels, rat serum samples obtained at the end of the micropuncture measurements were stored in aliquots of $50 \mu \mathrm{l}$ at $-70^{\circ} \mathrm{C}$. Sera were thawed, and $150 \mu \mathrm{l}$ of $0.5 \mathrm{M} \mathrm{HCl}$ was added, shaken vigorously, spun in a microcentrifuge, and incubated for $2 \mathrm{~h}$ at room temperature. To separate the IGF-I from the binding proteins, acidified samples were filtered through C-18 Sep Pak columns (Waters Associates, Millipore Corp., Milford, MA) that had been primed with $5 \mathrm{ml}$ of isopropanol, $5 \mathrm{ml}$ of methanol, and $10 \mathrm{ml}$ of $7 \%$ acetic acid. The columns were eluted with $1.0 \mathrm{ml}$ of methanol, and samples were concentrated in a Speed Vac concentrator (Savant Instruments, Inc., Farmingdale, NY). Samples were taken up in assay buffer and incubated overnight at $4^{\circ} \mathrm{C}$ before assaying.

The radioimmunoassay was performed using the nonequilibrium technique and a 3-d preincubation period, as described by Furlanetto and co-workers (26) using ${ }^{125}$ I-IGF-I (Amersham Corp., Arlington Heights, IL) as tracer. For each assay, three standard sera, obtained from a rat serum pool, were extracted in the same way as described for the samples. The standard curve was constructed from serial dilutions of the combined extracted standards. For the primary antibody we used the UBK 458 antibody at a final dilution of 1:18,000. This antibody was obtained from the Hormone and Pituitary Program, National Institutes of Health, Bethesda, MD. UBK 458 antibody was raised against purified human IGF-I by Dr. Louis Underwood and Dr. Judson van Wyk, University of North Carolina, Chapel Hill, NC. The antibody is known to result in different displacement curves when incubated with diluted human or rat serum, respectively. Although we infused human rhIGF-I into rats, we decided to use the pooled rat serum standard rather than rhIGF-I. This pool serum was arbitrarily assigned an IGF-I radioimmunoactivity of $1 \mathrm{U} / \mathrm{ml}$.

\section{Calculations and statistics}

The whole kidney GFR was calculated as the renal clearance of $\left[{ }^{3} \mathrm{H}\right]-$ inulin. The single nephron glomerular filtration rate (SNGFR) was determined from the clearance of $\left[{ }^{3} \mathrm{H}\right]$ inulin on timed proximal tubular fluid collections. The transglomerular hydrostatic pressure gradient $(\Delta P)$ was calculated as $P_{G}-P_{B S}$ (glomerular capillary and urinary space hydrostatic pressures, respectively). The serum oncotic pressure $(\pi)$ was derived from the plasma protein concentration (C) employing a modification of the equation of Landis and Pappenheimer as follows (27):

$\pi=1.76 C+0.28 C^{2}$.

Afferent and efferent effective filtration pressures $\left(\mathrm{EFP}_{\mathrm{A}}, \mathrm{EFP}_{\mathrm{E}}\right)$ were defined as

$E F P_{\mathrm{A}}=\Delta P-\pi_{\mathrm{A}}$

$E F P_{\mathrm{E}}=\Delta P-\pi_{\mathrm{E}}$.
The nephron filtration fraction, SNFF, is defined as

$S N F F=1-\left(C_{\mathrm{N}} / C_{\mathrm{E}}\right)$.

The single nephron plasma flow (SNPF) and blood flow (SNBF) rates were calculated as

$S N P F=S N G F R / S N F F$

$S N B F=S N P F /(1-H C T)$.

The afferent and efferent arteriolar resistances $\left(\mathbf{R}_{A}, R_{E}\right)$ are defined as

$R_{\mathrm{A}}=\left(M A P-P_{\mathrm{G}}\right) / S N B F$

$R_{\mathrm{E}}=\left(P_{\mathrm{G}}-P_{\mathrm{E}}\right) /(S N B F-S N G F R)$

where MAP refers to the mean systemic arterial pressure and $P_{E}$ is the efferent arteriolar hydrostatic pressure.

The computation of the glomerular ultrafiltration coefficient, LpA, was based on a standard model of the glomerular capillary as a righ circular cylinder with negligible resistance to axial flow and unity dimensions; in the model the SNGFR follows the equation

$S N G F R=L p A \int E F P(x) \mathrm{d} x \quad 0 \geq x \leq 1$

with $x$ being the normalized axial position along the unit capillary; and

$E F P(x)=\Delta P-\pi(x)=\Delta P-\left[1.76 C(x)+0.28 C^{2}(x)\right]$

and $C$ satisfies the following differential equation with the minimum condition $C(0)=C_{\mathrm{A}}$ and the maximum condition $C(1)=C_{\mathrm{E}}$ :

$\left[L p A * E F P(x) * C^{2}(x)\right] /\left[S N P F * C_{\mathrm{A}}\right)-\mathrm{d} / \mathrm{d} x C(x)=0$.

The equations are solved by stepwise predicting unique SNGFR values with the input of the independent determinants of the SNGFR, namely $\triangle P, S N P F$, and $C_{A}$, as well as $C_{E}$.

All results are presented as the mean \pm SEM. Comparisons of group means were performed with a one-way analysis of variance and the Newman-Keuls Multicomparison test.

\section{Results}

Pilot studies indicate that the dose of IGF-I needed to increase SNGFR in the unstarved rats was greater than that required for the 2.5-3.0 d food-deprived animals. The same dose of IGF-I also increased plasma IGF-I to a lesser degree in the nonstarved rats as compared with the food-deprived animals. Therefore, the unstarved rats were given a greater dose of IGF-I that raised the SNGFR and plasma IGF-I to about the same levels as in the food-deprived animals (see Methods, Table I).

Study 1 . The rat's body weight was $\sim 10 \%$ greater in the IGF-I-treated nonstarved rats as compared with the nonstarved controls (Table I). Left kidney weight, mean arterial pressure, and hematocrit were similar in the two groups. On the other hand, the serum IGF-I levels and the GFR in the IGF-I-treated nonstarved rats were each significantly greater than in the nonstarved controls. Serum IGF-I and left kidney GFR in the former animals were 2.3 and 1.4 times, respectively, the control values (Table I).

There was no significant effect of the IGF-I treatment on the glomerular capillary pressure, $P_{G}$, or the transglomerular capillary hydrostatic pressure difference, $\Delta \mathrm{P}$ (Table II). The mean effective filtration pressure (EFP) tended to be lower in IGF-I-treated nonstarved animals as compared with controls, but the difference was not statistically significant.

Even though the ultrafiltration pressure did not increase in the nonstarved IGF-I-treated rats, the SNGFR in these ani- 
Table I. Characteristics of Rats in Study 1 and Study 2

\begin{tabular}{|c|c|c|c|c|c|c|c|}
\hline Group & $n$ & BW & $\mathbf{K W}_{\mathbf{L}}$ & MAP & HCT & Serum IGF-I & $\mathbf{G F R}_{\mathbf{L}}$ \\
\hline & & $g$ & $g$ & $m m H g$ & vol\% & $U / m l$ & $\mathrm{ml} / \mathrm{min}$ \\
\hline \multicolumn{8}{|l|}{ Study 1} \\
\hline 1) Nonstarved controls & 6 & $195 \pm 3$ & $0.88 \pm 0.02$ & $121 \pm 3$ & $47 \pm 1$ & $0.76 \pm 0.08$ & $0.90 \pm 0.09$ \\
\hline 2) Nonstarved IGF-I-treated & 8 & $215 \pm 4$ & $0.85 \pm 0.02$ & $121 \pm 3$ & $48 \pm 1$ & $1.75 \pm 0.48$ & $1.26 \pm 0.08$ \\
\hline \multicolumn{8}{|l|}{ Study 2} \\
\hline 3) Food-deprived control & 6 & $184 \pm 8$ & $0.85 \pm 0.04$ & $105 \pm 3$ & $53 \pm 1$ & $0.41 \pm 0.04$ & $0.79 \pm 0.10$ \\
\hline 4) Food-deprived IGF-I-treated & 6 & $196 \pm 10$ & $0.84 \pm 0.03$ & $108 \pm 2$ & $51 \pm 1$ & $1.66 \pm 0.07$ & $1.15 \pm 0.11$ \\
\hline 1 vs. 2 & & $P<0.05$ & NS & NS & NS & $P<0.05$ & $P<0.05$ \\
\hline 3 vs. 4 & & NS & NS & NS & NS & $P<0.05$ & $P<0.05$ \\
\hline 1 vs. 3 & & NS & NS & $P<0.05$ & $P<0.05$ & $P<0.05$ & NS \\
\hline 2 vs. 4 & & NS & NS & $P<0.05$ & $P<0.05$ & NS & NS \\
\hline
\end{tabular}

Data expressed as mean \pm SEM. BW, body wt; $\mathrm{KW}_{\mathrm{L}}$, left kidney wt; $\mathrm{GFR}_{\mathrm{L}}$, GFR of left kidney.

mals was markedly elevated above the control levels (Table II, Fig. 1). SNPF and SNBF were also higher in the rats receiving the injection and infusion of IGF-I as compared with the controls. The former group tended to have a slightly higher SNFF, but this value was not significantly different from the control rats (Table I, Fig. 1). The efferent arteriolar resistance was significantly lower in the IGF-I-treated animals as compared with controls. Since there was also a tendency for $\mathbf{R}_{\mathrm{A}}$ to be lower in the IGF-I-treated rats, $P_{G}$ did not drop significantly below control values. However, the main difference among the determinants of nephron filtration was in the glomerular ultrafiltration coefficient, LpA, where values in the IGF-I-treated rats were about twice that observed in the normal controls (Table II, Fig. 1).

Study 2. The control rats subjected to $2.5-3.0 \mathrm{~d}$ of food deprivation had significantly lower serum IGF-I concentrations as compared with the nonstarved control rats (Table I). The administration of IGF-I raised serum IGF-I levels to about four times the values in the food-deprived controls $(P<0.05$, Table I). There were no differences between the two groups of food-deprived rats in Study 2 with regard to body weight, left kidney weight, hematocrit, or mean arterial blood pressure ( $\mathrm{Ta}$ - ble I). The mean arterial blood pressure was lower and the hematocrit was higher in the food-deprived IGF-I-treated or control rats as compared with the IGF-I-treated or control nonstarved Study 1 rats (Table I). GFR levels in the fasted control rats were slightly but not significantly lower than in the nonstarved control animals. However, with infusion of IGF-I, the left kidney GFR of the food-deprived rats increased significantly (Table I).

The administration of IGF-I had no effect on $P_{G}$ or $\Delta P$. The $\Delta \mathrm{P}$ was significantly lower in the starved IGF-I-treated and control rats as compared with the IGF-I-treated animals that were not starved. There was a tendency for the mean EFP to be lower in the starved IGF-I-treated rats as compared with the starved control animals; this difference was not statistically significant (Table II). As in the nonstarved rats, with IGF-I treatment of the food-deprived animals, even though the ultrafiltration pressure did not increase, the SNGFR rose significantly in comparison to the controls (Table II, Fig. 1).

In the food-deprived control rats not receiving IGF-I, the SNGFR was significantly lower in comparison to the nonstarved control rats that did not receive IGF-I (Table II, Fig. 1). Treatment with IGF-I increased the SNGFR in fasted rats, but

Table II. Glomerular Hemodynamics in Rats in Study 1 and Study 2

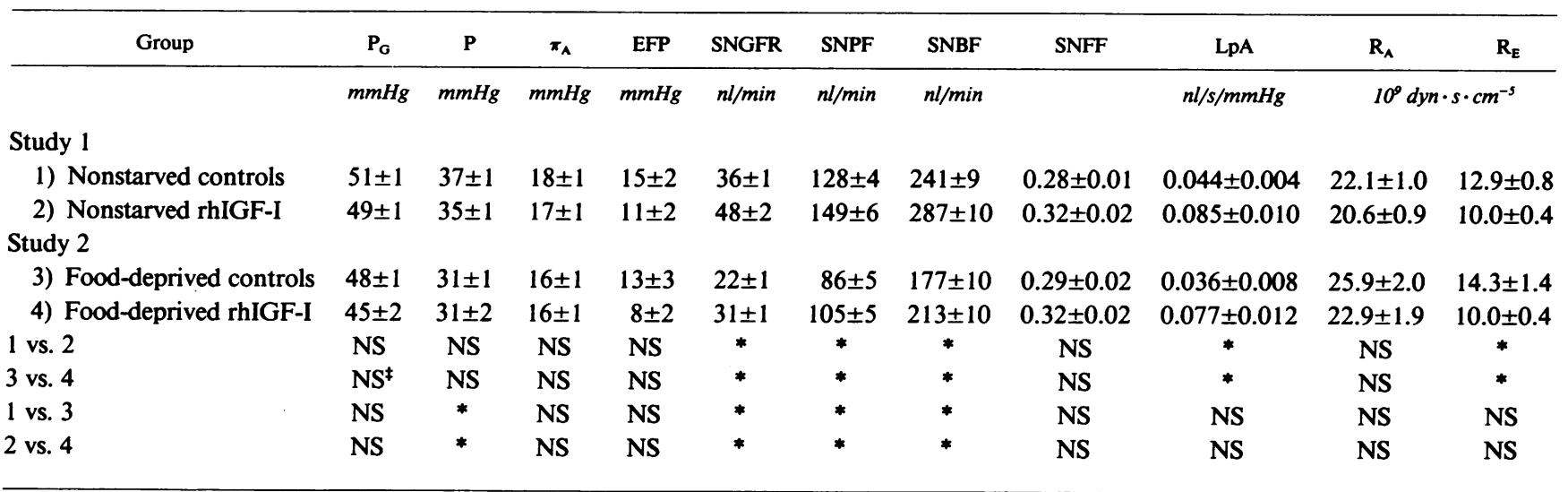

Data expressed as mean \pm SEM. ${ }^{*}$ Significant $(P<0.05) ;{ }^{\ddagger} P=0.09$. 

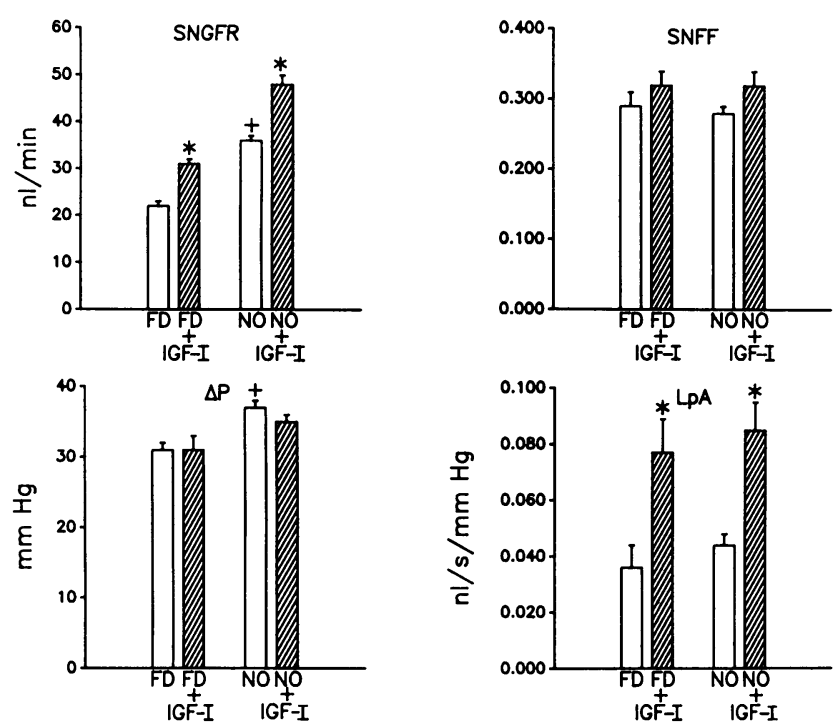

Figure 1. Major determinants of nephron filtration in normal, unstarved $(N O)$ and food-deprived $(F D)$ rats without or with IGF-I administration.

the values did not become normal. Similar relationships were observed for SNPF and SNBF. In the fasted rats, both SNPF and SNBF rose significantly with IGF-I treatment. However, in both the IGF-I-treated or control fasted rats, SNPF and SNBF were each significantly lower as compared with the respective groups that were not starved (Table II).

The increase in glomerular perfusion and filtration during IGF-I treatment occurred without a change in the SNFF, although the starved rats receiving IGF-I tended to have higher SNFF values. As in the nonstarved rats, treatment with IGF-I exerted a vasodilatory effect on glomerular arterioles. There was a small, statistically not significant, decrease in $R_{A}$. However, $R_{E}$ was, on an average, $30 \%$ lower in the starved IGF-Itreated rats as compared with the starved controls $(P<0.05$, Table II). Hence, the resulting increase in SNPF contributed to the rise in SNGFR. Nonetheless, the major factor causing the increase in SNGFR with IGF-I treatment appeared to be a rise in LpA. The values in the IGF-I-treated food-deprived rats were twice as high as in the respective controls $(P<0.05$, Table II, Fig. 1).

In addition to the effects of IGF-I on glomerular dynamics, the fractional proximal reabsorption of tubular fluid (FR) was also measured in the food-deprived rats. Fractional proximal reabsorption averaged $18 \%$ lower in the starved IGF-I-infused animals as compared with controls. Values were $0.50 \pm 0.02$ and $0.59 \pm 0.02(P<0.05)$ in the IGF-I-treated and control rats, respectively.

\section{Discussion}

Previous work in our laboratory as well as by other investigators indicated that a rise in serum IGF-I increases RPF and GFR $(17,19-22)$. The present studies examined the mechanisms giving rise to these changes. RhIGF-I infusion increased left kidney GFR, SNGFR, SNBF, and SNPF. One of the mechanisms responsible for the increase in SNBF and SNPF was a significant $30 \%$ reduction in $R_{E}$. The increase in SNGFR was caused by the rise in SNPF, but even more so by the doubling of the glomerular permeability coefficient (LpA). The fact that these findings were observed in two experimental models of rats (i.e., nonstarved rats and rats sustaining short-term, 60-72 $\mathrm{h}$ starvation) increases the likelihood that these findings reflect real effects of IGF-I infusion on the kidney.

The results of these studies indicate that rhIGF-I increases SNGFR largely by raising LpA. It appears to be rather unusual for a vasoactive compound to increase LpA. However, Gabbai and co-workers recently reported that another vasoactive substance, the $\alpha_{1}$-agonist methoxamine, also increases LpA (28). The ability of rhIGF-I to increase SNGFR by raising LpA is possible only because the animals studied operated at filtration pressure disequilibrium. In other animals that normally operate at filtration pressure equilibrium, rhIGF-I may still increase LpA but this would not be expected to result in an increase in SNGFR. Furthermore, this rise in LpA could not be measured with current methods. In filtration pressure equilibrium, rhIGF-I may still increase SNGFR through its effect on the arteriolar resistance and SNPF. It is pertinent that an infusion of rhIGF-I into adult humans increases RPF and GFR to a similar magnitude as occurs in the Munich Wistar rat (21).

The mechanism by which rhIGF-I increases LpA is not known. It may be pertinent that another growth factor, epidermal growth factor (EGF), acutely reduces glomerular perfusion and filtration when it is infused into the renal artery of rats (29). This effect is thought to be primarily due to an acute reduction in LpA as well as an increase in the afferent and efferent arteriolar resistances. Thus, IGF-I has opposite effects to EGF on glomerular perfusion and filtration. Harris and co-workers demonstrated that the effects of EGF on renal dynamics are mediated through arachidonate metabolites (30). In this regard, we have previously shown that the IGF-I-induced rise in RPF and GFR in fasted rats could be blocked by indomethacin (20).

Among the control rats not given IGF-I, the food-deprived animals displayed lower serum IGF-I, SNGFR, SNBF, and SNPF as compared with the nonstarved rats (Table II). The reduced SNGFR in the former animals was probably primarily due to a lower $\Delta \mathrm{P}$ and probably LpA. Although the LpA was not significantly different among the food-deprived control rats, $\mathrm{LpA}$ was reduced by $18 \%$ as compared with a decrease of $16 \%$ for $\triangle P$. The lower SNBF and SNPF in the fasted control rats appeared to be due to their slightly greater $R_{A}$ and $R_{E}$, although neither of these values was significantly different from the nonstarved controls (Table II).

These findings are comparable to other reports of reduced SNGFR and LpA in malnourished rats (31). Ichikawa and coworkers induced protein and possibly calorie malnutrition in rats and observed decreased SNGFR and LpA. The reduced SNGFR was primarily due to the reduced $L p A ; P_{G}$ and $\Delta P$ were unchanged. These investigators suggested that the reduction in LpA was largely, but not entirely, due to a decrease in the volume of the glomerular tuft.

In these studies, the short-term treatment with rhIGF-I in the food-deprived rats significantly increased SNGFR, SNBF, and SNPF. However, the SNGFR and SNPF in these animals remained below the levels of the nonstarved control rats (Table II, Fig. 1). The rise in SNGFR was largely due to an increase in LpA; $P_{G}$ and $\Delta P$ did not change significantly. The increase in SNBF and SNPF was primarily due to the fall in the glomerular 
efferent arteriolar resistance and contributed to the rise in SNGFR.

It is possible that a reduction in serum and/or renal IGF-I levels plays a role in the decrease in glomerular hemodynamics that occurs with malnutrition. Protein and/or calorie malnutrition reduces IGF-I synthesis (32) and serum and tissue IGF-I concentrations (32-34). In malnourished rats, there is also a significant decrease in renal IGF-I mRNA and an increase in the specific membrane binding of IGF-I in the kidney (32). An acute infusion of rhIGF-I causes an improvement or normalization in some of the same glomerular hemodynamic parameters that are reduced in malnourished rats. Despite this circumstantial evidence, the results of this study do not prove that a decrease in IGF-I levels was the sole mechanism or even one of several causes for the reduction in renal hemodynamic parameters during starvation.

It is unclear why in the nonstarved rats higher doses of rhIGF-I were necessary to raise plasma IGF-I and increase left kidney GFR to the same levels as in the food-deprived animals (Table I). It is possible that, in malnutrition, adaptive mechanisms come into play that reduce IGF-I degradation or that maintain serum IGF-I concentrations more effectively. Serum IGF-I binding proteins fall with starvation and the specific membrane binding of IGF-I increases (32); whether these factors increase sensitivity to IGF-I in the food-deprived rats is unknown.

The doses of rhIGF-I used in this study raised serum IGF-I levels to approximately twice normal (Table I). These serum concentrations are within the range seen in certain disease states; serum IGF-I levels of three to four times normal occur in acromegalics who also manifest increased RPF and GFR (18, 35 ). However, normally about $95 \%$ of serum IGF-I is protein bound. In the IGF-I-treated rats it is likely that a much higher proportion of serum IGF-I was not protein bound due to its acute administration. In this sense, the serum IGF-I concentrations in the IGF-I-treated rats might have been increased above physiological or pathophysiological levels. It is possible that the increases in serum or renal IGF-I levels that may occur in physiological or pathological conditions may not cause the changes in glomerular or hemodynamic parameters observed in this study. Further research will be necessary to resolve this question.

\section{Acknowledgments}

The authors greatly appreciate the donation of the rhIGF-I by Dr. Hans-Peter Guler, Ciba-Geigy, Summit, NJ. We also appreciate the donation of the IGF-I antibody by Dr. Louis Underwood and Dr. Judson Van Wyk, Chapel Hill, NC. The antibody was donated to the National Institutes of Health's National Hormone and Pituitary Program from where it was obtained for these studies.

These studies were supported by grants from the National Kidney Foundation of Southern California (to R. Hirschberg), the Research and Education Institute, Harbor-UCLA Medical Center (to R. Hirschberg), the American Heart Association (to R. Hirschberg), and the NIH, DK-39900 (to B. J. Tucker).

\section{References}

1. Svoboda, M. E., and J. J. Van Wyk. 1985. Purification of somatomedin C/insulin-like growth factor. I. Methods Enzymol. 109:798-816.
2. Roberts, C. T., S. R. Lasky, W. L. Lowe, Jr., W. T. Seaman, and D. LeRoith. 1987. Molecular cloning of rat insulin-like growth factor I complementary deoxyribonucleic acids: differential messenger ribonucleic acid processing and regulation by growth hormone from extrahepatic tissues. Mol. Endocrinol. 1:243-248.

3. D'Ercole, A. J., and L. E. Underwood. 1987. Estimation of tissue concentrations of somatomedin C/insulin-like growth factor I. Methods Enzymol. 141:227-233.

4. D'Ercole, A. J., A. D. Stiles, and L. E. Underwood. 1984. Tissue concentrations of somatomedin C: further evidence for multiple sites of synthesis and paracrine or autocrine mechanisms of action. Proc. Natl. Acad. Sci. USA. 81:935-939.

5. Andersson, G. L., A. Skottner, and E. Jennische. 1988. Immunocytochemical and biochemical localization of insulin-like growth factor I in the kidney of rats before and after uninephrectomy. Acta Endocrinol. 119:555-560.

6. Conti, F. G., L. J. Striker, S. J. Elliot, D. Andreani, and G. E. Striker. 1988. Synthesis and release of insulin-like growth factor I by mesangial cells in culture. Am. J. Physiol. 255 (Renal, Fluid, Electrolyte Physiol. 24):F1214-F1219.

7. Bortz, J. D., P. Rotwein, D. DeVol, P. J. Bechtel, V. A. Hansen, and M. R. Hammerman. 1988. Focal expression of insulin-like growth factor I in rat kidney collecting duct. J. Cell. Biol. 107:811-819.

8. Pillon, D. J., J. F. Haskell, and E. Meezan. 1988. Distinct receptors for insulin-like growth factor I in rat renal glomeruli and tubules. Am. J. Physiol. 255 (Endocrinol. Metab. 18):E504-E512.

9. Conti, F. G., L. J. Striker, M. A. Lesniak, K. MacKay, J. Roth, and G. E. Striker. 1988. Studies on binding and mitogenic effect of insulin and insulin-like growth factor I in glomerular mesangial cells. Endocrinology. 122:2788-2795.

10. Hammerman, M. R., and S. Rogers. 1987. Distribution of IGF receptors in the plasma membrane of proximal tubular cells. Am J. Physiol. 253 (Renal, Fluid, Electrolyte Physiol. 22):F841-F847.

11. Bar, R. S., M. Boes, and M. Yorek. 1986. Processing of insulin-like growth factors I and II by capillary and large vessel endothelial cells. Endocrinology. 118:1072-1080.

12. Stiles, A. D., I. R. Sosenko, A. J. D'Ercole, and B. T. Smith. 1985. Relation of kidney tissue somatomedin C/insulin-like growth factor I to postnephrectomy renal growth in the rat. Endocrinology. 117:2397-2401.

13. Fagin, J. A., and S. Melmed. 1987. Relative increase in insulin-like growth factor I messenger ribonucleic acid levels in compensatory renal hypertrophy. Endocrinology. 120:718-724.

14. El Nahas, A. M., J. E. Le Carpenter, A. H. Bassett, and D. J. Hill. 1989. Dietary protein and insulin-like growth factor I content following unilateral nephrectomy. Kidney Int. 36 (Suppl. 27):S15-S19.

15. Andersson, G., and E. Jennische. 1988. IGF-I immunoreactivity is expressed by regenerating renal tubular cells after inschaemic injury in the rat. Acta Physiol. Scand. 132:453-457.

16. Orlowski, C. C., and S. D. Chernausek. 1988. Discordance of serum and tissue somatomedin levels in growth hormone-stimulated growth in the rat. Endocrinology. 122:44-49.

17. Haffner, D., E. Ritz, O. Mehls, J. Rosman, W. Blum, U. Heinrich, and A. Hübinger. 1990. Growth hormone induced rise in glomerular filtration rate is not obliterated by angiotensin-converting enzyme inhibitors. Nephron. 55:63-68.

18. Ikkos, D., H. Ljunggren, and R. Luft. 1956. Glomerular filtration rate and renal plasma flow in acromegaly. Acta Endocrinol. 21:226-236.

19. Hirschberg, R., H. Rabb, R. Bergamo, and J. D. Kopple. 1989. The delayed effect of growth hormone on renal function in man. Kidney Int. 35:865870.

20. Hirschberg, R., and J. D. Kopple. 1989. Evidence that insulin-like growth factor I increases renal plasma flow and glomerular filtration rate in fasted rats. $J$. Clin. Invest. 83:326-330.

21. Guler, H-P., K. U. Eckardt, J. Zapf, C. Bauer, and E. R. Froesch. 1989. Insulin-like growth factor I increases glomerular filtration rate and renal plasma flow in man. Acta Endocrinol. 121:101-106.

22. Guler, H-P., C. Schmid, J. Zapf, and E. R. Froesch. 1989. Effects of recombinant insulin-like growth factor I on insulin secretion and renal function in normal human subjects. Proc. Natl. Acad. Sci. USA. 86:2868-2872.

23. Blantz, R. C., K. S. Konnen, and B. J. Tucker. 1978. Measurements of Glomerular Dynamics. In Methods in Pharmacology. M. Martinez-Maldonado, editor. Plenum Publishing Corp., New York. 141-163.

24. Lowry, O. H., N. J. Rosebrough, A. L. Farr, and R. J. Randall. 1951. Protein measurement with the Folin phenol reagent. J. Biol. Chem. 193:265-275.

25. Yoshioka, T., H. Shiraga, Y. Yoshida, A. Fogo, A. D. Glick, W. M. Deen, J. R. Hoyer, and I. Ichikawa. 1988. "Intact nephrons" as the primary origin of proteinuria in chronic renal disease. Study in the rat model of subtotal nephrectomy. J. Clin. Invest. 82:1614-1623.

26. Furlanetto, R. W., L. E. Underwood, J. J. Van Wyk, and A. J. D'Ercole. 1977. Estimation of somatomedin-C levels in normals and patients with pituitary disease by radioimmunoassay. J. Clin. Invest. 60:648-657.

27. Landis, E. M., and J. R. Pappenheimer. 1964. Exchange of substances 
through the capillary walls. In Handbook of Physiology. Section 2, Circulation. J. Orloff and R. Berliner, editors. American Physiological Society, Washington, DC. 961-1034.

28. Gabbai, F., B. Tucker, J. Pelayo, and R. Blantz. 1990. Effect of $\alpha_{1}$-adrenoreceptor stimulation on glomerular hemodynamics and glomerular ultrafiltration coefficient (LpA). Kidney Int. 37:551. (Abstr.).

29. Harris, R. C., R. L. Hoover, H. R. Jacobson, and K. F. Badr. 1988. Evidence for glomerular actions of epidermal growth factor in the rat. J. Clin. Invest. 82:1028-1039.

30. Harris, R. C., K. A. Munger, K. F. Badr, and K. Takahashi. 1990. Mediation of renal vascular effects of epidermal growth factor by arachidonate metabolites. FASEB (Fed. Am. Soc. Exp. Biol.) J. 4:1654-1660.

31. Ichikawa, I., M. L. Purkerson, S. Klahr, J. L. Troy, M. Martinez-Maldon- ado, and B. M. Brenner. 1980. Mechanism of reduced glomerular filtration rate in chronic malnutrition. J. Clin. Invest. 65:982-988.

32. Lowe, W. L., Jr., M. Adamo, H. Werner, C. T. Roberts, Jr., and D. LeRoith. 1989. Regulation by fasting of rat insulin-like growth factor I and its receptor. Effects on gene expression and binding. J. Clin. Invest. 84:619-626.

33. Isley, W. L., L. E. Underwood, and D. R. Clemmons. 1983. Dietary components that regulate serum somatomedin-C concentrations in humans. $J$. Clin. Invest. 71:175-182.

34. Phillips, L. S., and S. Goldstein. 1987. Molecular regulation of IGF-I in diabetic and fasted/refed rats. J. Endocrinol. Invest. 10 (Suppl. 4):18. (Abstr.).

35. Lamberts, S. W. J., P. Uitterlinden, and T. Verleun. 1987. Relationship between growth hormone and somatomedin-C levels in untreated acromegaly, after surgery and radiotherapy and during medical therapy with Sandostatin (SMS 201-995). Eur. J. Clin. Invest. 17:354-359. 